\title{
Market Reactions of the Pharmaceutical Sub-Sector to the Announcement of the Covid - 19 Incident in Indonesia
}

\author{
Erni Alfisah
}

\begin{abstract}
A capital market is a meeting place for capital seekers and capital owners who want to benefit from their investment. The market will respond quickly to any information directly related to the economic environment and the non-economic environment. This event study research aims to analyze differences in abnormal returns and trading volume activity in three different observation windows on the announcement of the Covid-19 incident in Indonesia in pharmaceutical sub-sector companies listed on the Indonesia Stock Exchange in 2020. This type of research used is all pharmaceutical subsector companies. On the IDX to be the study population. The sampling method used purposive sampling and obtained eight companies. AR \& TVA calculations with daily data are the analytical techniques used, obtained through www.idx.co.id. This study did not show any difference in AAR from all observation periods, namely five days before and after, ten days before and after, and 15 days before and after the event, for differences in ATVA were found in all observation periods.

Keywords: Abnormal return, Trading volume activity, Event study, The announcement of the Covid-19 incident in Indonesia..
\end{abstract}

\section{INTRODUCTION}

Investment has now become a general term for ordinary people and people who work in the economic and business fields. For companies to strengthen capital and develop business, companies issue stocks and bonds to invest. A capital market is a meeting place for capital seekers and capital owners who want to benefit from their investments (1).

The market will respond quickly to any information directly related to the economic environment and the non-economic environment. The form of an event (event) can change the stock price in the capital market due to some form of information. The event that you want to examine in this research is the announcement of Coronavirus Disease 2019 (Covid-19) in Indonesia by the President of the Republic of Indonesia, Jokowi Widodo, at the Presidential Palace, which was announced on Monday, March 2, 2020. Quoted from www.katadata.co.id The majority of Southeast Asian countries' economies are growing negatively and are threatened with the recession, one of which is Indonesia; this is due to reduced economic activity due to the Covid-19 pandemic (2).

Revised Manuscript Received on December 05, 2020.

* Correspondence Author

Erni Alfisah*, Faculty of Economics, Universitas Islam Muhammad Arsyad Al Banjari Banjarmasin, Banjarmasin, Indonesia. Email: alfisaherni@yahoo.co.id

(C) The Authors. Published by Blue Eyes Intelligence Engineering and Sciences Publication (BEIESP). This is an open access article under the CC BY-NC-ND license (http://creativecommons.org/licenses/by-nc-nd/4.0/)
Table 1. History of the Composite Stock Price Index (IHSG) and Pharmaceutical Indices during the observation period

\begin{tabular}{|c|c|c|c|c|c|}
\hline \multirow{2}{*}{$\begin{array}{l}\text { Observation } \\
\text { Period }\end{array}$} & \multicolumn{2}{|c|}{ Indeks } & \multirow{2}{*}{$\begin{array}{l}\text { Observation } \\
\text { Period }\end{array}$} & \multicolumn{2}{|c|}{ Indeks } \\
\hline & IHSG & Pharmacy & & IHSG & Pharmacy \\
\hline$(\mathrm{T}-15)$ & 5952 & 1973 & $(\mathrm{~T}+1)$ & 5518 & 1797 \\
\hline (T-14) & 5954 & 1968 & $(\mathrm{~T}+2)$ & 5650 & 1835 \\
\hline (T-13) & 5913 & 1920 & $(\mathrm{~T}+3)$ & 5638 & 1838 \\
\hline (T-12) & 5871 & 1901 & $(\mathrm{~T}+4)$ & 5498 & 1811 \\
\hline (T-11) & 5866 & 1908 & $(\mathrm{~T}+5)$ & 5136 & 1690 \\
\hline (T-10) & 5867 & 1906 & $(T+6)$ & 5220 & 1727 \\
\hline (T-9) & 5886 & 1908 & $(\mathrm{~T}+7)$ & 5154 & 1749 \\
\hline (T-8) & 5928 & 1922 & $(\mathrm{~T}+8)$ & 4895 & 1694 \\
\hline (T-7) & 5942 & 1938 & $(\mathrm{~T}+9)$ & 4907 & 1707 \\
\hline (T-6) & 5882 & 1912 & $(\mathrm{~T}+10)$ & 4690 & 1610 \\
\hline (T-5) & 5807 & 1884 & $(\mathrm{~T}+11)$ & 4456 & 1520 \\
\hline$(\mathrm{T}-4)$ & 5787 & 1873 & $(\mathrm{~T}+12)$ & 4330 & 1463 \\
\hline (T-3) & 5688 & 1844 & $(\mathrm{~T}+13)$ & 4105 & 1376 \\
\hline (T-2) & 5535 & 1800 & $(\mathrm{~T}+14)$ & 4194 & 1482 \\
\hline (T-1) & 5452 & 1743 & $(\mathrm{~T}+15)$ & 3989 & 1397 \\
\hline (T-0) & 5361 & 1729 & & & \\
\hline
\end{tabular}

Based on data from www.yahoofinance.co.id, there was a change in the closing of the JCI or Agricultural Index after the policy was announced, namely on trading on Tuesday (3/3/2020), the Composite Stock Price Index (IHSG), and the Pharmaceutical Index closed higher (3). Changes in return or price of the security for information or events reflect a reaction (4).

Researchers are trying to conduct a study of events regarding the relationship with abnormal returns (AR) and trading volume activity (TVA) on the announcement of the Covid 19 incident in Indonesia. In this study, researchers are interested in choosing listed and active companies on the Indonesia Stock Exchange in the pharmaceutical sub-sector in 2020 as research objects because the emergence of external information, the Covid-19 incident in Indonesia, indirectly affects trade in the pharmaceutical sub-sector. The observation period carried out in the study was 30 days (covering 15 days before and after the event, ten days before and after the event, and five days before and after the event); this was done to be able to find out which period had a clear difference in reaction — an event.

Published By:

Blue Eyes Intelligence Engineering \& Sciences Publication

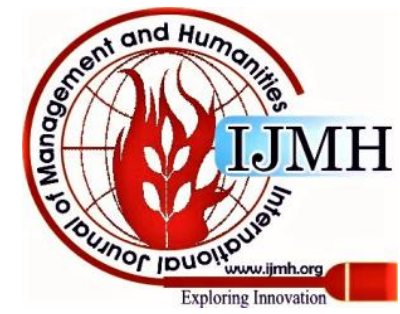




\section{Hypothesis}

The hypothesis is compiled based on the results of research from previous studies, namely:

1. Before and after the event, the average difference in abnormal returns is found (the results of the study (5).

2. After and before an incident, a difference in the mean trading volume of activity was found (hasil penelitian (6).

So the research hypothesis is:

H1 : 5 days after \& 5 days before the announcement of the Covid - 19 incident in Indonesia, differences were found in AAR.

H2 : 10 days before \& 10 days after the announcement of the Covid - 19 incident in Indonesia, differences in AAR were found.

H3 : 15 days before \& 15 days after the announcement of the Covid - 19 incident in Indonesia, differences in AAR were found.

H4 : 5 days before \& 5 days after the announcement of the Covid - 19 incident in Indonesia, differences in ATVA were found.

H5 : 10 days before \& 10 days after the announcement of the Covid - 19 incident in Indonesia, differences in ATVA were found.

H6 : 15 days before \& 15 days after the announcement of the Covid - 19 incident in Indonesia, differences in ATVA were found.

\section{MATERIALS AND METHODS}

They knew how the Indonesian capital market's reaction before and after the announcement of the Covid-19 incident in Indonesia for shares of the pharmaceutical sub-sector listed on the IDX in 2020. Study of the type of research events used, all pharmaceutical sub-sector companies on the IDX, are studied. The sample used a purposive sampling method and obtained eight companies.

AR \& TVA calculations with daily data are the analytical techniques used, obtained through www.idx.co.id (7) and www.yahoo.co.id (3). The paired sample t-test is different from the test model used.

\section{RESULTS AND DISCUSSION}

Descriptive Statistical Analysis

Descriptive Statistics Average Abnormal Return (AAR)

Descriptive statistics from AAR after and before the announcement of the Covid - 19 event in Indonesia in 2020 with 10, 20 \& 30 days observations are presented in the following table:

Table 2. Descriptive Statistics of AAR

\begin{tabular}{|c|c|c|c|c|c|}
\hline & $\mathbf{N}$ & Mean & $\begin{array}{c}\text { Std. } \\
\text { Deviasi }\end{array}$ & Minimum & Maximum \\
\hline $\begin{array}{l}\text { AAR } \\
\text { Before }\end{array}$ & 5 & -0.0100912 & 0.00904324 & -0.02005 & 0.00353 \\
\hline $\begin{array}{l}\text { AAR } \\
\text { After }\end{array}$ & 5 & 0.0124826 & 0.03181526 & -0.01273 & 0.06480 \\
\hline $\begin{array}{l}\text { AAR } \\
\text { Before }\end{array}$ & 10 & -0.0054658 & 0.01302761 & -0.02005 & 0.02475 \\
\hline $\begin{array}{l}\text { AAR } \\
\text { After }\end{array}$ & 10 & 0.0016958 & 0.03269999 & -0.06269 & 0.06480 \\
\hline $\begin{array}{l}\text { AAR } \\
\text { Before }\end{array}$ & 15 & -0.0043706 & 0.01142918 & -0.02005 & 0.02475 \\
\hline $\begin{array}{l}\text { AAR } \\
\text { After }\end{array}$ & 15 & 0.0081981 & 0.03701550 & -0.06269 & 0.09247 \\
\hline
\end{tabular}

In the 10-day observation period, the AAR before the lowest or minimum of -0.02005 occurred in the T-1 period. The maximum or highest value of AAR before the event was 0.00353 during the T-5 observation period. Then, in the period after the announcement, the lowest AAR value, namely -0.01273 , occurred in the $T+4$ period. The maximum or highest AAR value after the announcement was 0.06480 occurred in the $T+3$ observation period.

In the 20-day observation period, before the lowest AAR was -0.02005 occurred in the T-1 period. The maximum or highest AAR value before the announcement was 0.02475 , which occurred in the T-8 observation period. Then, in the period after the policy was announced, the minimum AAR value, namely -0.06269 , occurred in the $T+7$ period. After the announcement was announced, the maximum or highest AAR value was 0.06480 , which occurred during the $\mathrm{T}+3$ observation period.

In the 30-day observation period, before the lowest AAR was -0.02005 occurred in the T- 1 period. The maximum or highest AAR value before the announcement was 0.02475 , which occurred in the T-8 observation period. Then, in the period after the policy was announced, the minimum AAR value, namely -0.06269 , occurred in the $T+7$ period. After being announced, the maximum or highest AAR value was 0.09247 occurred in the observation period $T+15$.

Descriptive Statistics of Average Trading Volume (TVA)

Descriptive statistics of ATVA after and before the Covid - 19 incident in Indonesia in 2020 with 10, 20, and 30 days observations, are presented in the following table:

Table 3. Descriptive ATVA

\begin{tabular}{lccccc} 
& N & Mean & Std. Deviasi & Minimum & Maximum \\
\hline ATVA Before & 5 & 0.00040700 & 0.000156175 & 0.000245 & 0.000626 \\
ATVA After & 5 & 0.00152380 & 0.000725383 & 0.000816 & 0.002736 \\
\hline ATVA Before & 10 & 0.00039250 & 0.000166639 & 0.000178 & 0.000699 \\
ATVA After & 10 & 0.00112560 & 0.000652928 & 0.000531 & 0.002736 \\
\hline ATVA Before & 15 & 0.00038127 & 0.000143427 & 0.000178 & 0.000699 \\
ATVA After & 15 & 0.00110653 & 0.000654645 & 0.000517 & 0.002736 \\
\hline
\end{tabular}

In the 10-day observation period, ATVA before the lowest or minimum of 0.000245 occurred in the T-4 period. The maximum or highest value of ATVA before the announcement was worth 0.000626 occurred in the T-1 observation period. Then, in the period after, the minimum value of ATVA, namely 0.000816 , occurred in the $T+5$ period. Twenty days of observation, ATVA before the lowest or minimum value of 0.000178 occurred in the $\mathrm{T}-10$ period. The maximum or highest value of ATVA before the event of 0.000699 occurred in the T-8 observation period. Then, in the period after the incident, the minimum value of ATVA, namely 0.000531 , occurs in the $\mathrm{T}+8$ period. The maximum or highest value of ATVA after the event of 0.002736 occurs in the $\mathrm{T}+3$ observation period. Thirty days of observation, ATVA before the lowest or minimum value of 0.000178 occurred in the T-10 period. The maximum or highest value of ATVA before the event of 0.000699 occurred in the T-8 observation period.

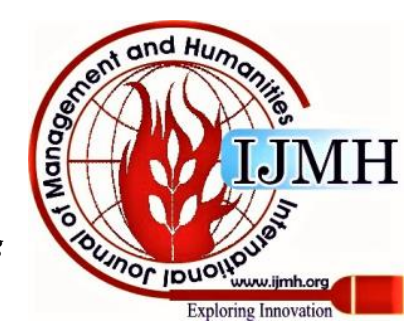


Then, in the period after the incident, the minimum value of ATVA, namely 0.002736, occurred in the $\mathrm{T}+3$ observation period. The maximum or highest value of ATVA after the event of 0.002736 occurs in the $\mathrm{T}+3$ observation period.

\section{Normality test}

Normality Test for AAR

The normality test for AAR before and after the announcement of the Covid - 19 incident in Indonesia in 2020 with the entire observation period, is presented as follows:

Table 4. AAR Normality Test

\begin{tabular}{llll}
\hline & AAR Before & AAR After & Explanation \\
\hline $\mathrm{N}$ & 5 & 5 & \\
\hline Asymp.Sig. (2-tailed) & 0,200 & 0,200 & Normal \\
\hline $\mathrm{N}$ & 10 & 10 & \\
\hline Asymp.Sig. (2-tailed) & 0,200 & 0,194 & Normal \\
$\mathrm{N}$ & 15 & 15 & \\
\hline Asymp.Sig. (2-tailed) & 0,200 & 0,187 & Normal \\
\hline
\end{tabular}

In 10 days of observation, the number of $\mathrm{N}$ based on the observation period's length is ten days. Asymp.Sig. or AAR's P-value before 0.200 exceeds 0.05 , and AAR's P-value after 0.200 exceeds 0.05 , which can be interpreted as d or AAR is normally distributed. Then, 20 days with the number of $\mathrm{N}$ based on the length of the observation period, namely 20 days. The AAR P-value results before, namely, 0.200 exceeding 0.05 , and after being valued at 0.194 exceeding 0.05, which means that AAR is normally distributed during the study period, and 30 days with the number of based on the length of the observation period of 30 days. The results of the P-value of AAR before, namely, 0.200 exceeding 0.05 , and after being valued at 0.187 exceeding 0.05 , which can be interpreted as normal AAR distributed during the study period.

\section{Normality Test for ATVA}

The ATVA normality test before and after the announcement of the Covid - 19 incident in Indonesia in 2020, for the entire observation period, is presented as follows:

Table 5.Normality Test Results on ATVA

\begin{tabular}{llll}
\hline & ATVA Before & ATVA After & Explanation \\
\hline $\mathrm{N}$ & 5 & 5 & Normal \\
\hline $\begin{array}{l}\text { Asymp.Sig. } \\
(2 \text {-tailed })\end{array}$ & 0,200 & 0,112 & \\
\hline $\mathrm{N}$ & 10 & 10 & Normal \\
\hline $\begin{array}{l}\text { Asymp.Sig. } \\
(2 \text {-tailed })\end{array}$ & 0,200 & 0,200 & Normal \\
\hline $\mathrm{N}$ & 15 & 15 & \\
\hline $\begin{array}{l}\text { Asymp.Sig. } \\
(2 \text {-tailed })\end{array}$ & 0,086 & 0,091 & \\
\hline
\end{tabular}

The observation period is ten days, with the amount based on the observation period's length, namely ten days. The results of the P-value of ATVA before were 0.200 more than 0.05 , and the P-value of ATVA after 0.112 was more than 0.05, which means that ATVA was normally distributed. Then, the observation is 20 days, with the number based on the observation period's length, which is 20 days. The results of the P-value of ATVA before were 0.200 more than 0.05 and the P-value of ATVA after a value of 0.200 more than 0.05, which means that the ATVA data is normally distributed, and the observation is 30 days, with the amount based on the length of the observation period of 30 days. . The results of the P-value of ATVA before were 0.086 more than 0.05 and the P-value of ATVA after being valued at
0.091 was more than 0.05 , which could mean that the ATVA data were normally distributed.

\section{Hypothesis testing}

\section{First hypothesis test}

Tests were carried out to determine whether differences were found between the AAR 5 days before and the AAR 5 days after the event was announced. The following test results are presented as follows:

Table 6. First Hypothesis Test

10 Day Observation Period (5 Days Before and 5 Days After)

\begin{tabular}{lcc}
\hline & $\begin{array}{c}\text { Asymp.Sig. } \\
(2 \text {-tailed })\end{array}$ & Explanation \\
\hline AAR Before - AAR After & 0,193 & There is no difference \\
\hline
\end{tabular}

The AAR test in 10 days of observations shows the value of Sig. namely $0.193>0.05$, so it means that there is no difference in AAR, then the first hypothesis is rejected.

\section{Second Hypothesis Test}

Tests were carried out to determine whether any differences were found between AAR 10 days before and AAR 10 days after the event was announced. The results of the test are seen as follows:

Table 7. Test results on the Second Hypothesis

Observation Period 20 Days (10 Days Before and 10 Days After)

\begin{tabular}{lcc}
\hline & $\begin{array}{c}\text { Asymp.Sig. } \\
(2-t a i l e d)\end{array}$ & Explanation \\
\hline AAR Before - AAR After & 0,440 & There is no difference \\
\hline
\end{tabular}

AAR testing 10 days before and after the event showed the Asymp.Sig. namely $0.440>0.05$, so the second hypothesis is rejected.

\section{Third Hypothesis Test}

Tests were carried out to determine whether any differences were found between AAR 10 days before and AAR 10 days after the event was announced. The results of the test are seen as follows:

Table 8. Test results on the Third Hypothesis

Observation Period 30 Days (15 Days Before and 15 Days After)

\begin{tabular}{lcc}
\hline & $\begin{array}{c}\text { Asymp.Sig. } \\
(2-\text { tailed })\end{array}$ & Explanation \\
\hline AAR Before - AAR After & 0,238 & There is no difference \\
\hline
\end{tabular}

AAR testing 15 days before and after the event showed the Asymp.Sig. namely $0.238>0.05$, so the third hypothesis is rejected.

\section{Fourth Hypothesis Test}

The test was carried out to find out whether any differences were found between ATVA 5 days before \& 5 days after the event was announced, it can be seen in the following table:

Table 9. Testing on Hypothesis Four

10 Day Observation Period (5 Days Before and 5 Days After)

\begin{tabular}{lcc}
\hline & $\begin{array}{c}\text { Asymp.Sig. } \\
(2 \text {-tailed })\end{array}$ & Explanation \\
\hline ATVA Before - ATVA After & 0,032 & $\begin{array}{c}\text { There is no } \\
\text { difference }\end{array}$ \\
\hline
\end{tabular}

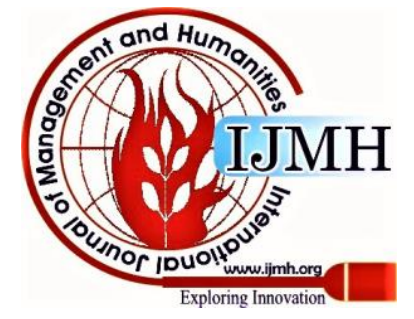


ATVA testing 5 days before and 5 days after the event shows the Sig value is $0.032<0.05$, so hypothesis four is accepted.

\section{Fifth Hypothesis Test}

The test was carried out to find out whether any differences were found between ATVA 10 days before \& 10 days after the event was announced, it can be seen in the following table:

Table 10. Testing on the Fifth Hypothesis

Observation Period 20 Days (10 Days Before and 10 Days After)

\begin{tabular}{lcc}
\hline & $\begin{array}{c}\text { Asymp.Sig. } \\
(2 \text {-tailed })\end{array}$ & Explanation \\
\hline ATVA Before - ATVA After & 0,004 & There is a difference \\
\hline
\end{tabular}

ATVA testing 10 days before and 10 days after the event showed the Sig value of $0.004<0.05$, so the fifth hypothesis was accepted.

\section{Sixth Hypothesis Test}

The test was carried out to find out whether any differences were found between ATVA 15 days before \& 15 days after the event was announced, it can be seen in the following table:

Table 11. Testing on the Sixth Hypothesis

Observation Period 30 Days (15 Days Before and 15 Days After)

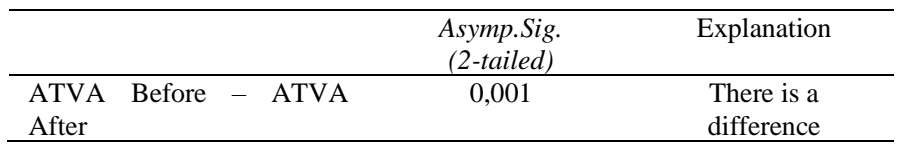

ATVA testing 15 days before and 15 days after the event showed a Sig value of $0.001<0.05$, so the sixth hypothesis was accepted.

\section{Discussion of Average Abnormal Return Results}

The results of testing the first, second, and third hypotheses stated that there were no differences before and after the announcement of the Covid-19 incident in Indonesia in the pharmaceutical sub-sector companies in 2020. This study's results support the results of previous studies conducted by Yudiawan et al. (2020), which states that there is no difference in the average abnormal return before and after the event (Yudiawan \& Abundanti, 2020). These results prove that the information regarding the announcement of the Covid - 19 incident in Indonesia does not affect transaction activities, especially on stock prices, so that no investor can take advantage of excessive returns before and after the announcement took place. The absence of a difference indicates that the event's information is not strong enough so that there is no significant difference before and after the event with the average abnormal return in all observation periods. This is also possible because the market had anticipated the information contained in advance. After all, before the virus entered Indonesia, many other countries had already felt the impact, so that market players speculated or made buying and selling in a short time.

Discussion on the Results of Average Trading Volume Activity

The results of testing the fourth, fifth, and sixth hypotheses show that there are differences after the announcement of the Covid - 19 incident in Indonesia in the pharmaceutical sub-sector company in 2020. The results of previous research conducted by Kayana et al. (2018) state that there are differences in trading volume activity before and after the event (8). These results prove that the information studied on the Covid - 19 incident in Indonesia affected trading activity, especially on trading volume. The movement of the average trading volume activity is different from the average abnormal return; the average trading volume activity fluctuates both before the event and after the event; an increase in a positive direction is greater than the average trading volume that occurs after the Covid-19 announcement on period $\mathrm{T}+3$. An average trading volume activity during the observation period was because the information contained in the event was considered good (good news) by investors. In general, the announcement of Covid - 19 in Indonesia is indeed bad news (bad news) for the business world. However, market participants have learned from experience in past events. During the Covid-19 pandemic, the pharmaceutical sub-sector market players may think stocks related to health will experience trade changes.

\section{CONCLUSION AND RECOMMENDATION}

Based on the discussion that has been delivered, it can be concluded that there is no difference in AAR in the entire observation period. Then there are differences in ATVA throughout the observation period.

This research recommends that companies be advised to manage finances effectively and efficiently, because the Covid-19 outbreak / virus in Indonesia is increasingly widespread and the time for completion cannot be predicted. By managing finances properly, the company can increase company value which will also enrich shareholders so that investors are increasingly interested in investing.

\section{REFERENCES}

1. Tandelilin E. Portofolio dan Investasi Teori dan Aplikasi. Yogyakarta: Kanisius; 2010. 129713 p.

2. Yudhistira AW, Jayani DH. Covid-19 Menjatuhkan Ekonomi Asia Tenggara. Katadata.co.id. 2020;

3. Historical Data. Jakarta Composite Index. 2020;

4. Hartono J. Teori Portofolio dan Analisis Investasi Edisi 11 Yogyakarta: BPFE; 2017.

5. Nisa C, Astutu M, Mariana CD. Dampak Merjer dan Akuisisi Terhadap Abnormal Return Saham Perusahaan Di Indonesia Periode 2016-2018. J Ris Manaj Sains Indones. 2019;10(1):44-70.

6. Kayana FN, Tommy P, Maramis JB. Reaksi Investor Pasar Moda Indonesia Tehadap Pengumuman Dividen (Studi Kasus Pada Perusahaan Asuransi Yang Terdaftar Di Bursa Efek Indonesia Tahun 2016-2017). J EMBA J Ris Ekon Manajemen, Bisnis dan Akunt. 2018;6(3):1208-17.

7. PT Bursa Efek Indonesia. Ringkasan Indeks. 2020

8. Yudiawan PA, Abundanti N. Reaksi Pasar terhadap Peristiwa Pemilihan Presiden Tahun 2019 di Bursa Efek Indonesia. E-Jurnal Manaj. 2020;9(2):799-818. 